\title{
RATIONALITY AND RESPONSIBILITY: BENCHMARKS TO RE-EVALUATE THE LAW IN THE CONTEXT OF THE PANDEMIC CRISIS
}

\author{
Rodica CIOBANU 1
}

DOI: 10.35782/JCPP.2021.2.01

\begin{abstract}
Human and social vulnerability in the face of the pandemic once again raises the question of knowledge and of the two key dimensions of the individual (rationality and responsibility) framed in the various relationships they establish (with nature, with other individuals, with state institutions etc.). These become relationships of knowledge and awareness concerning the facts and laws of social-state organization. Being aware that the pandemic crisis left its mark on all areas of life, changing the nature of human relations, affecting the benchmarks of values, and requiring a review of the foundations of social organization, we believe it necessary to assess the current situation through a systemic approach aimed at identifying the benchmarks of the balance between individuality and sociality. Thanks to the assessment of the interdependencies between the individual and the social, the following objectives were addressed: to define the changes caused by the pandemic and analyze the social processes; to validate the decisions taken by the authorities from a logical, praxeological and axiological point of view; to emphasize the importance of norms and principles in the social organization; to determine the role of social actors in overcoming the crisis, and to assess how social relations have evolved under pandemic conditions. Therefore, the present article, applying an interdisciplinary methodology to the pandemic crisis, aims to evaluate, understand and raise awareness of the situation and its impact on the social and human situation, where solidarity, rationality, and human responsibility are being reassessed.
\end{abstract}

Keywords: rationality; responsibility; pandemic crisis; interdisciplinarity; social system; buman action; rules; principles.

\section{Overall contextual analysis}

The problem of dependency in the relationship among person-state-law, has had different forms of manifestation. This kind of relationship has become highly important due to the global outreach of the Covid-19 pandemic crisis, in a century in

$1 \mathrm{PhD}$, associate professor, Department director, Moldova State University, e-mail: rod.ciobanu@ gmail.com, phone: (+373) 69387887 
which the most diverse scenarios on the future where modeled, but none of them included the scenario of the current pandemic crisis that the human, the society, or the states are going through.

The White Paper on the future of Europe, presented by the European Commission (CE) in 2017 (White Paper on the Future of Europe), considering the main challenges and opportunities (the impact of technologies, the impact of the globalization, security issues and growing populism), has presented five scenarios on how Europe could evolve by 2025. Simultaneously with these scenarios and the immediate implementation following the adoption of the White Paper, a series of documents appeared which include topics such as the development of the social dimension of Europe and the exploitation of the globalization opportunities. Also relevant is The Rome Declaration (March 25, 2017) in which the EU leaders presented their commitment: '[i]n these times of change, and aware of the concerns of our citizens, we [...] pledge to work towards [...] [a] social Europe [-] a Union which, based on sustainable growth, promotes economic and social progress as well as cohesion and convergence [...], a Union taking into account the diversity of national systems [...], which promotes equality [...], fights unemployment, discrimination, social exclusion and poverty; a Union where young people receive the best education and training and can study and find jobs across the continent $[\ldots]$ ' (The Rome Declaration). The most important aspect that we deduce from this citation is, probably, the formula in which the awareness of problematic situations and convergent actions between authorities and citizens that are needed to foster social cohesion and cooperation is emphasized.

The history of Europe and humanity has periodically been marked by turning moments that have put the states and people on test. The current crisis seems to have left its mark on all aspects of life, changing the nature of human relations, actions, or the benchmarks. The awareness of the factual and legal concern of the situation is an attempt to pass from ignorance to knowledge, to develop some solutions in order to minimize the impact. Thus, the trajectory is from realism to pragmatism, framing and modelling the future scenarios with methods and possible solutions. Even if some scenarios which have been formulated along the history have turned out to be false, they are the only way to approach the unpredictability of the future. The impossibility to forecast the technological progress and its consequences, the social processes and political developments has led in the past to many erroneous predictions. For example, Margaret Thatcher mentioned, in 1969, 'many years will pass by before a woman becomes prime minister, but not during my lifetime' (Dale, 2020). Ten years later, she became the prime minister (EU and the East in 2030, p.9). Now, in relation to the pandemic crisis, we seek to understand and raise awareness of the situation, on the impact on the current social and human environment. Humans and society, through decisions taken by the public authorities, have begun to reshape themselves by revaluing solidarity, rationality and human accountability.

At the same time, the human and social vulnerabilities created by the pandemic once again raise the issue of knowledge and of the two priority hypostases through which the person manifests in various relationships (with nature, with other people, with state institutions etc.). These are generalized in relations of knowledge and of awareness of realities and rules, according to which the social-state existence is organized, as a 
rational and responsible person. Of course, with a certain dose of skepticism, we will consider that since the rapid onset of the pandemic we have gone through several emotional phases: from it cannot affect us, the problem is not as serious as it is circulating in public space, it cannot influence our life in a substantial way etc., to a realistic acknowledgment of the crisis impact here and now, and concerns about tomorrow. Initial skepticism has been replaced by an acute realism of the pandemic crisis and its impact upon the life of the individual, society, economy etc. Pragmatic considerations have triggered critical scientific approaches, directed to move from ignorance to knowledge, through an ongoing and complex process of searching for a solution to problems affecting social and individual security.

Therefore, on one hand, the knowledge becomes important and on the other hand, the methods of knowing and searching for solutions too. Moreover, the current construction of social relations highlights the promotion and the priority of two principles (theoretical-methodological and pragmatic): rationality (theoretical and practical) and accountability, which corresponds with the emphasis placed in the formulas of inter-, multi- and transdisciplinary methodologies oriented towards distinct realities, such as the one configured by the crisis caused by Covid-19. What could be the solution? The extremes? Or maybe there is a golden middle through and beyond the current crisis, promoted around the notions of sustainable development, person, state, law, in which decision-makers recognize that among the fundamental elements (food, housing, infrastructure, health, social care etc.), education though training of the rational and accountable person is at the foreground, because among the factors that will increasingly influence the future of our economies and societies are education and competencies (The Rome Declaration). Essentially, we are living at a moment of deadlock that has emphasized the pragmatism, but also the realism, which seeks to foresee the consequences that have a major impact on the nature of relations among people themselves, between people and institutions, between people, the state and law, between theory and practice, between ideal and reality.

\section{Milestones of the balance between individuality and sociality}

In general, any theoretical-methodological approach, by capitalizing on systemicity, identifies the proximity of realities and practices that are adopted by institutions and their representatives, of the appreciation by citizens of the efficiency of institutions by assessing the performance and the professionalism of each representative, and of the quality of decisions. In this regard, with the rapidly evolving global pandemic, international bodies, in particular the World Health Organization or national Governments have called the societies and individuals to be aware of the gravity of the situation and to take maximum responsibility. The restrictive measures applied during the quarantine period intended to balance the impact and "limit some rights in order to respect the rights and freedoms of others" (Universal Declaration of Human Rights, Paris, 1948), whereas the limitation is nothing else but the accountability of everyone to themselves and to everyone else. Thus, responsibility is currently an attribute, an accessory with which international bodies, national governments, state institutions, 
central and local authorities, mass-media, civil society, and educational institutions operate. It is also a quality of each individual person. In this 'fuss ' of responsibility it is necessary that individuals do not exercise their accountability in isolation, but in coordination with institutions and through social connection with others, even if we have to secure the 'social distance' (Sikkink, 2020). This formula of social accountability involves the three concepts of solidarity (the person, the state and the law) to which official decisions, protection measures and common and individual actions are linked, and on which the social and emotional developments of the pandemic crisis depend. The most interesting fact is that the issues of social responsibility, solidarity, conscience were considered, until recently, irrelevant, and the debates about them were considered exhausted and outdated by scientific communities. However, this is not the case at the beginning of this century.

In spite of this, the balance between individuality and sociality is ensured by the individual and collective responsibility that aims to protect the collective right to health in the current pandemic situation. As the work 'The Hidden Face of Rights: Toward a Politics of Responsibility argues, in order to fully assume human rights, it is necessary to place major emphasis on the responsibility of all social actors, not only on the responsibility of states. Most of the time, when discussing law, politics, justice, the language of rights and freedoms is used, and less often the one of responsibilities. At the same time, the role and the responsibility of the state for the protection of human rights is emphasized, but considerably less articulated provisions regarding the obligations of other social actors (The Hidden Face of Rights: Toward a Politics of Responsibility`argues. Paper Review). In a traditional formula, responsibility was seen as the predecessor of accountability, but now, as Sikkink (2020) points out, referring to the model of retroactive responsibility or the model based on accountability, we must take another approach, not retrospective, which answers the question who is to blame?, but prospective, which answers the question what should we do? This formula is relevant to the critical situation caused by Covid-19, being necessary to try to think the society from the perspective of what will be after the pandemic, how it will change in the face of humanity, what will be the dominant norms and values, which were the bigger mistakes that which of them must be avoided. The basic sources in the analysis of crises indicate, in particular, that the systemic crises that society is going through at a given moment determines an increase of the degree of probability of major value and institutional changes. Should this change be a change towards the re-evaluation of human responsibility and solidarity?

The answer to the question could be provided only through convergent and complex approaches, by applying the arsenal of inter-, multi- and transdisciplinary methodologies, by systemic analyzes and by assessing the nature of interdependencies of the most diverse origin, but especially focused on the re-evaluation of human performance in person-state-law configuration. In particular, the interdisciplinary approach to the relationship in question (person-state-law) in the current conditions is relevant for:

- the definition of the changes caused by the pandemic and the analysis of social processes; 
- the validation of the applied measures from a logical, praxiological and axiological point of view;

- the interpretation of the social system by emphasizing the dominant character of the legal norm, but also through the competition of all the other categories of social norms;

- the establishment of the major role of each entity (person, state, law) in overcoming the social crisis, in increasing practical efficiency;

- the analysis of the way in which the person-state - law relationship evolves in the conditions of connecting to the global circuit.

The Weberian conception of responsibility from an ethical perspective, which aims not only at intention but also at the most effective way of action (Weber, 1998, p.56) as well as the positivist one (presented by R. Dworkin (1998), is particularly relevant in this conjuncture, with reference to the character and the nature of a public morality.

Having as a reference the systemic approach and the current methodologies, we will realize the detachment of the dimensions of the interdisciplinary methodology in configuring the landmarks of the importance of the reciprocal relations between person, state and law in the current conditions of the pandemic crisis.

Starting from the fact that the legal system represents a compartment of the integral social system, we will indicate that through interdisciplinary mechanisms, the interconnection of the law system to the realities of the social system is simplified. $\mathrm{V}$. Zlătescu (1995, p.11) expressed his regret as early as in 1995 for the fact that the legal science did not make more efforts to accept the principles of the general theory of systems and to adapt them to its specificity, because the need for a system in law is so great that apart from this idea it is not possible to legislate. The system of law represents (...) an immanent structural ensemble, having organic coherence and a dynamic balance, an ensemble that presents itself as a qualitative invariant, according to which any norm is defined in relation to the whole, mentions I. Huma (1993, p.101), in 'Introducere in studiul dreptului [Introduction to the Study of Law]. So, the term legal system is a characteristic of the law and we can consider that it enjoys maximum generality, being attributed not only to the legal system and the system of legislation, but also to the institutions that realize the law, the principles of law, the values underlying the legal system. As a social normative form, the law bears the imprint of the system in which it is functional, indicating that all legal norms reflect fundamental, structural relations, has an internal coherence, which ensures its functionality, applicability, expresses the interdependence of norms, forms an integral whole, which cannot be reduced to its component parts, or approached separately.

Regardless of the way of understanding (either as a subsystem of the social system, or as a system of general principles, or as a system of values etc.), consensus is reached in the idea that all systems are made up of a set of elements, ordered in a certain internal structure, characterized by a certain degree of complexity and pursue the same goal ensuring the social balance. Within the system, due to the interactions between the component elements, new properties may appear, that are not characteristic for the 
elements of origin and are a result of the dynamics of social processes. Thus, once a system element can cause, due to interactions with other elements, the appearance of new characteristics at the system level or due to very small internal changes, positive changes can also be achieved at the system level. Consequently, the integrative perspective of the interdisciplinary methodology confirms the possibility of reconfiguring the constituent elements of the system, so that the system retains its capacity for self-organization, in order to increase its efficiency and effectiveness. Now, having this opinion shared by other authors, concerned with the analysis of the legal system from the perspective of efficiency and overcoming entropy, in the conditions of contemporary law, circumscribed on the review of the person-state-law relationship as a philosophy of human rights, one can recognize the prioritization of the person (bomo juridicus) and the increasing importance of the reconceptualization of its role and place in the internal structuring of the law, as well as in increasing the efficiency and practical effectiveness in pandemic crisis situations, and not only. Thus, the factual dimension of the approach will determine the nature of the actions (acts) and the act of validation will operate with the normative-value substance of the persons (of homo juridicus).

The logical validation of law refers to the development of the epistemological dimension of law; in particular, by increasing the competitive and performing character of legal science, it will necessarily determine the capitalization of the society in the legal practice, determining the interaction between forms of rationality (theoretical and practical). Thus, the praxiological dimension will be separated from the epistemological one, being found, in particular, in human actions or in events, which, according to the legal norms, lead to the appearance, modification or extinction of the legal relations. Thus, legal facts, as a defining, constitutive, fundamental element of the legal reality, create, modify or extinguish legal relations (Foulcault, 2011, p.231).

The person manifests in the social framework through actions that, under normative prescriptions, are required to be rational and responsible, as well as overlaps its own values with the system of values of the society, with the values promoted by institutions. In this conjuncture, actions are an expression of human will, to which the rule of law binds legal consequences. If traditionally, we had the situation in which the vertiginous increase of legal regulations (the so-called overregulation) - so that the life of the individual was regulated by a wide variety of legal rules - rather led to a decrease in the degree of responsibility of persons, then we are currently witnessing a shift in emphasis, whereby measures taken by states have made it a priority to increase the degree of compliance and accountability of citizens, by limiting even some fundamental rights. At one pole is the theoretical legislative rationality, oriented towards a greater legislative coverage of the spheres of human action, so as to approach the practical rationality, and at another - the lack of practical rationality, on the background of a pronounced legal nihilism, the created situation affecting responsibility on the dimension of individuality and on the dimension of society.

The epistemic dimension, corresponding to the need to validate the law from the three perspectives (logical, praxiological and axiological), profiled on the tendency to seek solutions to overcome the crisis, configures the active role of the person in each of these three perspectives, especially on the dimension of return to normative areas, which have assumed, as a major goal, promoting, ensuring and respecting the norms 
and values around which human society has been organized and built, but at the moment are proving to be inefficient. Aiming to offer a global conception of law, revealing the reason of being, the foundations of categories and legal principles, the epistemological dimension of law appears completely clear only in the light of the unity between reality, knowledge and rationality, unity necessarily viewed both theoretically and from a methodological point of view (Wald, 1967, p.6).

M. Foulcault (2011), in [The Archaeology of Knowledge], points out that the legal rule and the scientific hypothesis, a literary work, the testimonies made by a person, a paper of criminal law, etc. are, at the same time, a component part of a culture, but also bearers of the culture in question. All of them (law, science, literature, poetry, etc.) are equally the result of a process of knowledge, consisting of a totality of instruments (concepts, procedures, mechanisms, etc.), statements and visible objects of law (prosecutors` offices, courts, penitentiaries, Constitutional Court, etc.). Therefore, in the view of M. Foulcault, knowledge presupposes two basic components: a substantive theoretical basis (necessary for the acceptance and follow-up of the decisions and restrictions taken by states in pandemic conditions) and a complementary practical rationality of the statement and of the visible object (that manifests itself in actions, concrete acts both of the representatives of the state institutions and of the persons, in their quality of rational and responsible beings). Regarding the way in which $\mathrm{M}$. Foucault treats legal knowledge, Poncela P. (1988, p.169-177) mentions that it offers a method, a way of analyzing what is said, an appeal to a general theory of product production, that must merge with a revolutionary practice in which the legal discourse acts, creates, functions, regardless of my life and my death.

It should be noted that the epistemic dimension of the interdisciplinary methodology reveals the differences in the status of the person in law, subject to legal scientific knowledge, in order to conjugate them in a unitary vision in which the person as a subject of rights, the person as a subject of knowledge, the person as a rational being, the person as a creator of laws, etc. meet. From a conjugated perspective, two essential formulas are outlined, in which the research of the person in law is oriented: that of homo sapiens, endowed with rationality, as an essential faculty that shapes him as a personality, and that of bomo juridicus, endowed with rights and freedoms, aware of his actions and able to be responsible. Depending on these two priority hypostases, the various relations the person establishes (with nature, with other people, with state institutions, etc.) are generalized in relations of knowledge and of awareness of the laws, according to which its social-state existence is organized, as a responsible person. Moreover, in this formula in which manifested and became indisputable not only the convergent action of all social actors (person, state, law), but also the integrated and conjugated approach to the situations that societies and states go through today, proves its usefulness the inter, multi and transdisciplinary methodology, which has increasingly gained ground starting with the second half of the twentieth century.

Through the systematization branch on the dimension of the realization of human knowledge, O. Hoffman (1999, p.181) identifies a series of functions that can be taken over and adapted to the development of the interdisciplinary methodology in the legal science: 
10 Benchmarks to re-evaluate the law in the context of the pandemic crisis

- takes place through the mechanisms of human thought, leading to a reflection through abstract forms, able to synthesize the general and essential elements of some classes of objects and properties, determining the continuous development of conceptual instruments of law and revealing the importance of legal conceptualism;

- acquires symbolic forms, which concentrate the great diversity of meanings that can be used, to denote numerous existential situations, by the abstract and relative character of the concepts (such as fairness, justice, equity, human rights, etc.), by technical tools that become applicable and useful for solving legal problems;

- implies a value dimension (through the meanings it gives to cognitive relations with practical experience, etc.), which, as a result, determines legal institutions;

- it is intentionally finalizing, assuming a purpose that it can serve and contributing to the capitalization and the development of the technical and operational instruments of the law;

- has a historical-concrete character, responding to concrete life situations and progressing as the general evolution of society, contributing to maintaining and following the legal ideal, monitoring and managing the implementation process in the practice of a social-state organization of ideas, such as the Rule of Law, such as ensuring the protection of human rights in conditions of pandemic crisis, etc.

Systematizing the previous ideas, we will mention that, in fact, in the current conditions, legal knowledge is necessary to be included in a new theoreticalmethodological format, which, by reference to the specific situation of legal issues caused by the pandemic crisis, turns into a discursive practice, i.e. an investigation, a research that seeks to comply with scientific rigors and standards, a space of manifestation of the subject, as a creator of laws and rights, and of the meanings (values) of objects included in his speech (public health, integrity, freedom, legality, etc.), in a context in which re-conceptualizations, re-evaluations, re-definitions are applied, transforming the law through a totality of discursive relationships and contextualization (scientific fields) or non-discursive practices.

Another dimension is the pragmatic one that highlights the way in which the man, as a subject of activity, conceives, analyzes reality, acts on it, the solutions of efficiency and effectiveness that could be proposed depending on it. Being involved in the diversity of social relations, the man wonders about his actions, his own deeds, the actions and deeds of the people around him. Through the rational dimension (revealed by epistemology), the man acts as a generic and axiological being (Hoffman, 1999, p.182). Referred to the person-state-law triad, a configuration that presupposes assessments of human performance from the combined perspective of theory and practice, two methodological tools are presented as benchmarks of actions and assessments of facts: rationality and responsibility. Human action, as it is treated in the literature, designates any significant human activity in relation to a structural component of the society, in the sense that it is determined or determines itself the place, the role or the function of that component in the structure of the law (the right to defense (art. 26), the right to free movement (art. 27), freedom of conscience (art. 31), freedom of opinion and expression (art. 32), the right to health care (art. 36), the right to a healthy environment 
(art. 37) ) etc. (Constitution of the Republic of Moldova) and in its functionality. That is why it is necessary to determine the nature of the relationship between the structural component and the functional one. There is a dogma, often invoked, that facts, as a result of activity and values, are distinct from a logical viewpoint. In this sense, Professor D. Borțun, who mentioned that in the public and private space there is a difference between what we think, say and what we do, states that, at the level of common sense, the vast majority of people pay attention only to what they say or hear and almost totally neglect the way they say, understand, act. This illusion of the modality is bizarre, if we think that, in the order of the acts (of the action), the modality, the procedure, the method, the ways are considered very important (Borțun, 2001).

People make assessments all the time, they make assessments of the same things differently, including the role of state institutions, the law is seen differently, in certain circumstances as an ally of the citizen or as a rival. Still D. Hume (2014) was inclined to state, in his works, that fundamental desires (welfare, fairness, equity, legality etc.) are shared by all human beings, so that we naturally approve or disapprove the same things. In this context, speaking about the appreciation of human behavior, it is very complicated to exclude values and norms from this area, because they presuppose human problems, they presuppose rationality and responsibility, involvement, participation and solidarity, they presuppose responsible and open to the society requests state institutions, as well as an efficient legal system.

\section{Conclusions}

In general, the theory of social action, by its interdisciplinary nature, is a field of interest for the law, for the political science, for anthropology, psychology, sociology, the leadership theory, economics, cybernetics, etc. In determining the nature of socialhuman actions/acts, a set of conditions participate, that compose the praxiological and the social-cultural context of the act, which involves the factors acquired and mastered by the person through education and which conditions the act: information on the natural and social context of the action; values and valuation criteria accepted by individuals; technical, cultural, human resources, etc.; the system of norms (moral, political, legal, etc.) that regulates and qualifies under certain aspects the activity of individuals.

Theories regarding social action, which are also called theories of action and rationality (Em. Durkheim, T. Parsons, A. Touraine, V. Pareto, M. Weber, etc.), highlight the relationships between the individual, the society/state and the law, revealing directions for exploring the social conduct of homo juridicus. From the structural-functional perspective of T. Parsons, social action is determined by dominant ideas and values of the society (Bulgaru, 2003, p.256), the social action being characterized by several structural elements, such as: human goals, the situation of action (conditions and means, circumstances), value orientations. If the means and conditions constitute the conditional side of the action, then the aims and the rules represent the normative side of the action. The way in which the means are appropriate for the purpose of the action will define the rationality of the human action. Starting from the analysis of the 
structure of human action, the axiological-normative determination of human actions is initiated in the foreground (the right to education (art. 35), the freedom of creation (art. 33), the right to free movement (art. 27), the right to vote and the right to be elected (art. 38.) etc. (Constitution of the Republic of Moldova) - all of them indicating the great diversity of human actions).

Thus, speaking about the rationality of human action in pandemic conditions, we can also talk about the fact that it would be an integrative social tool including all the activities through which a social system ensures its balance. At this point, we need to make a statement, namely: to indicate that not every human action / human deed is also a legal action / deed, just as not every human action is a social action. M. Weber (2013) says that human action becomes social only when its author assigns meaning to it in relation to the value orientations of the global social space. Professor Gh. Avornic (2009, p.108) opts for the analysis of legal acts in relation to the volitional criterion and shows that they are circumstances provided by legal rules, as a result of which arise, change or extinguish rights and obligations of participants in these social relations (legal relations), in other words, thus producing legal effects. We will plead for the extended formula of analysis and definition of the concept of the legal act, framed in the extension of the concept of action, due to the framework in which we seek to determine priorities of the status of the person, included in the state-law relationship, because, if we go back to the same author, who states that actions are legal acts committed voluntarily by subjects of law, which, according to legal norms, produce legal effects, then, regardless of the form in which the actions are found (intentionally or unintentionally), they presuppose formulas of manifestation of responsibility.

In the works of M. Weber (2013) we identify a typology of social action, which, conceptualized from a pragmatic perspective, indicates the field on which the two principles of the interdisciplinary methodology of law are indispensable: the principle of rationality (theoretical and practical) and of responsibility. The four types of actions, in an adapted and interpreted formula, reveal the vast area in which human behaviors are manifested and, at the same time, refer to the reasoning (in the sense of motivations) of actions: a) the traditional action, that designates behaviors of individuals, determined by custom and values, considered obvious, of which persons are partially aware, such as fundamental rights and freedoms; b) the affective action, determined by instincts and emotions, formulated and taken into account on various dimensions of public and private law (kinship relations, self-defense, action in a state of distress etc.); c) the rational action as a value, performed by individuals in accordance with personal beliefs, aware / or not of certain foreseeable consequences of their acts of will, materialized in concrete acts (false statements, participation in elections, etc.); d) the rational action as a finality reflects the behaviors of individuals who set their objectives and evaluate the most appropriate means for the purpose, but also involves the ability to appreciate and anticipate unwanted, vicious consequences (protest actions, referral to the Constitutional Court etc.). If rational action as a value appeals to the ethics of persuasion, rational action as an end presupposes an ethics of responsibility. Thus, rationality and responsibility represent social dimensions of the subject of the action, imposed and determined by the nature of social relations, especially by the current conditions of the global pandemic. Both concepts are forms of manifestation of the 
need to integrate the individual in the community, in order to preserve and develop the relationships between people, between people and institutions, and to their optimization through law.

\section{Authorship}

Ciobanu Rodica (CR) conceptualized and designed the study. She was responsible for the overall project supervision, for data curation and analyses. Ciobanu Rodica led the manuscript preparation and manuscript drafting.

\section{Acknowledgements}

This study was supported in part by the Institute of History within the Academy of Sciences of Moldova.

\section{Funding}

The author received no financial support for the research, authorship, and/or publication of this article.

\section{Declaration of conflicting interests}

The author declares no conflicting interests.

\section{References}

Avornic, G. (2009). Tratat de teoria generală a dreptului [Treaty of General Theory of Law]. Vol. I, Tipografia Centrala, Chisinau.

Borțun, D. (2001). Semiotica. Limbaj şi comunicare [Semiotics. Language and communication], Comunicare.ro, Bucuresti. [cited 12.11.2020]. Available: https://www.academia. edu/35884875/Lector_univ_dr_Dumitru_Bor\%C5\%A3un_SEMIOTIC\%C4\%82 _LIMBAJ_\%C5\%9EI_COMUNICARE

Bulgaru, M. (2003, coord.). Sociologia [Sociology], Vol. I., CEP USM, Chisinau.

Constitution of the Republic of Moldova, no.1 of 29.07.1994. In: Official Gazette of the Republic of Moldova, 12.08.1994, no.1.

Dale, I. (2020). The Prime Ministers. Hodder \& Stoughton Ltd, London.

Dworkin, R. (1998). Drepturile la modul serios [Taking rights seriously], Editura ARC, Chisinau.

Foulcault, M. (2011). Arheologia cunoasterii [The Archaeology of Knowledge], Editura RAO, Bucuresti.

Hoffman, O. (1999). Ştïnţă.Tehnologie. Valori [Science. Technology. Values]. Editura Lumina Lex, Bucuresti.

Huma, I. (1993). Introducere in studiul dreptului [Introduction in the study of law], Chemarea, Iasi. 
14 Benchmarks to re-evaluate the law in the context of the pandemic crisis

Hume, D. (2014). Cercetare asupra intelectului omenesc [An Enquiry Concerning Human Understanding7, Editura Ratio et Revelatio, Bucuresti.

Poncela, P., (1988). L`archeologie du savoir juridique. Archives de philosophie du droit. Vol.33. Sirey, Paris.

Popa, N. (2008). Teoria generală a dreptului [General Theory of Law], Editura CHBeck, Bucuresti.

Recenzie lucrare [Paper Review]. [cited 05.11.2020]. Available: https://yalebooks.yale. edu/book/9780300233292/hidden-face-rights

Sikkink, K. (2020). Drepturi și responsabilități în timpul pandemiei de Coronavirus [Rights and responsibilities during the Coronavirus pandemic]. [cited 03.11.2020]. Available: https://www.openglobalrights.org/rights-and-responsibilities-in-the-coronaviruspandemic/?lang=Romanian

The Rome Declaration. Declaration of the leaders of 27 member states and of the European Council, the European Parliament and the European Commission, 149/17, 25/03. [cited 03.11.2020]. Available: https://www.consilium.europa. $\mathrm{eu} / \mathrm{en} / \mathrm{press} /$ press-releases/2017/03/25/rome-declaration/pdf

UE şi Estul în 2030 [EU and the East in 2030]. [cited 05.11.2020]. Available: http://ier.gov.ro/wpcontent/uploads/2018/12/RO_Scenarii_EUEast2030_ptxt.pdf

Universal Declaration of Human Rights, Paris, December 10, 1948, pp.29. Available: https://www.un.org/en/universal-declaration-human-rights/

Wald, H. (1967). Elemente de epistemologie generală [Elements of general epistemology], Editura Stiintifica, Bucuresti.

Weber, M. (1992). Politica, o vocatie şi o profesie [The profession and Vocation of Politics], Editura Anima, Bucuresti.

Weber, M. (2013). Oraşul [The City]. Editura ALL, Bucuresti.

White Paper on the Future of Europe. Reflections and scenarios for the EU27 by 2025. European Commission, 1 March 2017 [cited 03.11.2020]. Available: https://ec.europa.eu/info/sites/info/files/white_paper_on_the_future_of_europ e_en.pdf

Zlătescu, V. (1995). Introducere în legistica formală [Introduction in formal legistics], Editura Rompit, Bucuresti. 